\title{
NOTE
}

\section{Pigment contaminants in polycarbonate filters}

\author{
Michele A. Burford, Peter C. Pollard* \\ CSIRO Division of Fisheries, Marine Laboratories, PO Box 120, Cleveland, Queensland 4163, Australia
}

\begin{abstract}
Membrane filters are often used to size fractionate phytoplankton when measuring biomass-specific production. Polycarbonate filters are reputed to have the lowest extractables for membranes used for environmental analysis. however, we show that Nuclepore ${ }^{(1)}$ polycarbonate filters contain a dye that co-extracts with algal pigments into methanol The contaminating dye has characteristics similiar to those of pigments extracted from mixed populations of naturally occurring phytoplankton when measured spectrophotometrically. The dye can, however, be separated from the chlorophylls using high performance liquid chromatography. In addition, the dye does not fluoresce and hence does not interfere with fluorometric analysis of chlorophyll $a$. The purpose of this note is to alert investigators to the presence of the contaminating pigment in Nuclepore ${ }^{\text {(j) }}$ polycarbonate filters which can be mistaken for algal pigments. Other brands, such as Poretics ${ }^{\otimes}$, do not contain the contaminant and could be used as an alternative
\end{abstract}

KEY WORDS: Pigments - Phytoplankton - Contaminants Polycarbonate filters

Studies of algal biomass and productivity rely on the use of membrane and glass-fibre filters (Joint \& Pomroy 1983, Furnas et al. 1990, Williams \& Claustre 1991). Membrane filters are used as sieves to fractionate algal groups according to their size. Although glass-fibre filters are the most commonly used type, membrane filters provide additional information about the size composition of the phytoplankton population. Filters are extracted into a suitable solvent and analysed using spectrophotometric, fluorometric and high performance liquid chromatography (HPLC) techniques.

In the course of our studies we have found a dye in the Nuclepore ${ }^{\circledR}$ polycarbonate filters that co-extracts

\footnotetext{
- Present address: Departments of Chemical Engineering and Microbiology, University of Queensland, Queensland 4072, Australia
}

with the naturally occurring pigments and could be confused with them. We compared the spectrophotometric, HPLC and fluorometric characteristics of the solvent extracts of polycarbonate filters containing natural phytoplankton populations collected in the Gulf of Carpentaria, Australia, and a laboratory culture of microalgae.

Methods. Water samples were collected in Albatross Bay, Gulf of Carpentaria, Australia, using 5 l Niskin bottles. Subsamples of $350 \mathrm{ml}$ were filtered under vacuum onto $47 \mathrm{~mm}$ diameter polycarbonate and glass-fibre filters. Three pore sizes were used to separate the main size classes of phytoplankton, i.e. 10,2 and $0.6 \mu \mathrm{m}$. Two brands of polycarbonate filter were used: Nuclepore ${ }^{(}$and Poretics ${ }^{*}$. These were compared with 1 brand of glass-fibre filter, Whatman ${ }^{\circ} \mathrm{GF} / \mathrm{F}$, with a nominal pore size of $0.7 \mu \mathrm{m}$. Five replicates were filtered onto each type of filter. Filters were snap-frozen in dry ice and stored at $-40^{\circ} \mathrm{C}$.

In order to determine the ratio of the filter contaminant to chlorophyll a when different quantities of phytoplankton are filtered, a laboratory culture of the green flagellate Tetraselmis suecica $\left(400 \mu \mathrm{m}^{3}\right)$ was filtered onto $0.6 \mu \mathrm{m}$ Nuclepore ${ }^{\otimes}$ and Poretics ${ }^{(}$polycarbonate filters, and Whatman ${ }^{\otimes}$ glass-fibre filters. Three volumes were used: 1,5 and $10 \mathrm{ml}$ with a cell concentration of $10^{6} \mathrm{ml}^{-1}$. Two replicates were filtered onto each type of filter; the replicates were then frozen at $-40^{\circ} \mathrm{C}$ prior to analysis.

In the laboratory the filters were shredded with scissors in $5 \mathrm{ml}$ of cold methanol and were ultrasonicated using a cell-disruptor microtip (Branson ${ }^{\circledR}$ ) for $1 \mathrm{~min}$ in the dark. Each sample was then filtered through a $0.22 \mu \mathrm{m}$ nylon membrane filter (Kosmidere Medical Pty, Ltd, Victoria, Australia). Filters without algae (blank controls) were also extracted using this procedure. Immediately after the pigments were extracted, the samples were scanned in a double beam UV-Vis 
spectrophotometer (Hitachi ${ }^{(} \mathrm{U}-2000$ ) between the 400 and $750 \mathrm{~nm}$ wavelengths at $400 \mathrm{~nm} \mathrm{~min}{ }^{-1}$. Glass cuvettes with a $1 \mathrm{~cm}$ path length were used. Samples extracted in methanol and acetone were also scanned using a spectrofluorometer (Hitachi ${ }^{2}$ F-2000) at the chlorophyll a maxima; excitation $417 \mathrm{~nm}$, emission $669 \mathrm{~nm}$.

Pigment extracts were injected into an HPLC system (Millipore Waters ${ }^{(1)}$ models M45 and 501 pumps). The solvent system was based on the method used by Gieskes \& Kraay (1983) and used a 2 solvent gradient: (A) $30 \%$ water in methanol and (B) $20 \%$ ethyl acetate in methanol. These solvents were pumped in a linear gradient from 20 to $100 \%$ of solvent B in $30 \mathrm{~min}$, followed by $15 \mathrm{~min}$ in $100 \%$ solvent $\mathrm{B}$. The solvents were run through a $3.9 \times 150 \mathrm{~mm}$ RP-C18 column (Novapak, Millipore Waters $\left.{ }^{\oplus}\right)$ at $1 \mathrm{ml} \mathrm{min}^{-1}$, programmed with a System Controller (Waters ${ }^{\circledR}$ Model 720 ) and detected at $436 \mathrm{~nm}$ (Waters ${ }^{\oplus}$ model 440 ). Peaks were automatically intregrated with a Hewlett Packard ${ }^{\otimes} 3394$ A integrator.

To identify peaks, eluted fractions were evaporated and redissolved in ethanol. An absorption spectrum was then obtained with a spectrophotometer (Hitachi ${ }^{(\infty)}$ U-2000). The spectra and HPLC retention times of the pigment extracts were compared with pigments isolated from laboratory cultures of Phaeodactylum tricornutum (Bacillariophyceae), Dunaliella tertiolecta (Chlorophyceae), Amphidinium carterae (Dinophyceae), Chroomonas salina (Cryptophyceae), Phaeocystis pouchetii (Prymnesiophyceae) and Oscillatoria $\mathrm{sp}$. (Cyanobacteria). The carotenoid pigments were also compared with published wavelength maxima of absorption spectra (Rowan 1.989).

Results. Spectra of the Nuclepore ${ }^{\infty}$ polycarbonate filter extracts, in the absence of phytoplankton, showed broad peaks at 400 and $650 \mathrm{~nm}$ (Fig. 1A) in the same region of maximum absorbance for carotenoid and chlorophyll pigments (Rowan 1989). The absorbance of Poretics ${ }^{\oplus}$ polycarbonate filter extracts in the $400 \mathrm{~nm}$ to

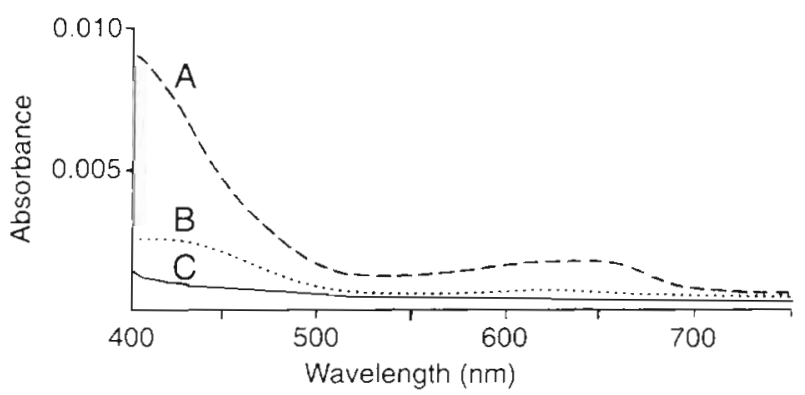

Fig. 1 Absorbance spectra for (A) Nuclepore and (B) Poretics ${ }^{\circ}$ polycarbonate filters, and (C) Whatman ${ }^{6}$ glass-fibre filters, extracted in methanol in the absence of phytoplankton

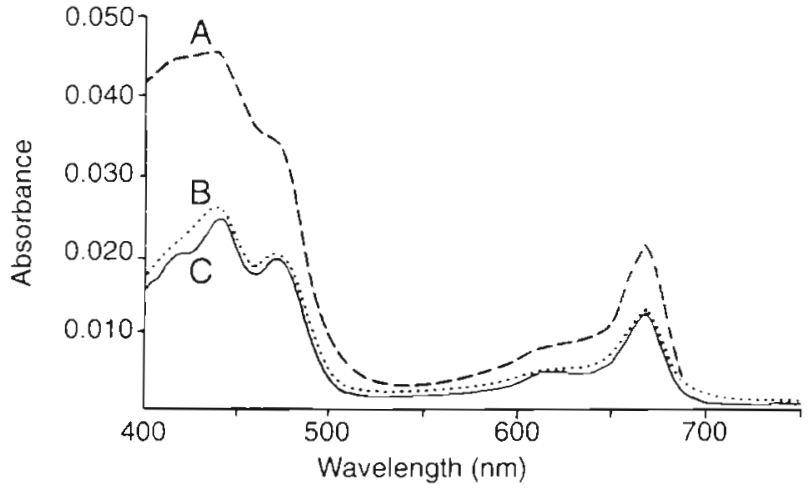

Fig. 2. Absorbance spectra for replicate phytoplankton samples filtered onto (A) Nuclepore ${ }^{6}$ and (B) Poretics ${ }^{\infty}$ polycarbonate filters, and (C) Whatman glass-fibre filters, and then extracted in methanol

$750 \mathrm{~nm}$ range was considerably lower (Fig. 1B). Extracts of Whatman ${ }^{(}{ }^{-}$glass-fibre filters had an absorbance no greater than 0.001 (Fig. 1C). Extracts of Nuclepore ${ }^{\circledast}$ polycarbonate filters, containing phytoplankton cells, also showed considerably higher chlorophyll a (665 nm) and carotenoid (420 to $480 \mathrm{~nm}$ ) absorbance than Poretics ${ }^{\circledR}$ and Whatman ${ }^{\circledR}$ extracts (Fig. 2). Thus the contaminant could not be distinguished from chlorophyll a when chlorophyll a was measured using wavelengths of $665 \mathrm{~nm}$ and $750 \mathrm{~nm}$, unless it was compared with an extracted blank filter.

The chlorophyll a that was measured from spectral readings of phytoplankton extracted on the 3 filter brands were compared (Table 1 ). Three pore sizes $(0.6$, 2 and $10 \mu \mathrm{m}$ ) of polycarbonate filters were used. GF/F glass-fibre filters have a nominal retention size of $0.7 \mu \mathrm{m}$ and were, therefore, only compared with $0.6 \mu \mathrm{m}$ polycarbonate filters. The contaminating dye in Nuclepore ${ }^{10}$ polycarbonate filter extracts of phytoplankton resulted in a consistent 20 to $30 \%$ increase in the measurements of chlorophyll $a$, irrespective of the pore size, when compared to Poretics ${ }^{\circ}$ and Whatman ${ }^{9}$ filter extracts.

Table 1. Mean and standard error of chlorophyll a concentrations $\left(\mu \mathrm{g} \mathrm{l}^{-1}\right)$ in methanol extracts of natural phytoplankton filtered onto Nuclepore polycarbonate, Poretics polycarbonate and Whatman ${ }^{\circ} \mathrm{G} / \mathrm{F}$ glass-fibre filters. Three pore sizes, $0.6,2$ and $10 \mu \mathrm{m}$, of the polycarbonate filters were used Phytoplankton samples $(350 \mathrm{ml})$ were collected from $20 \mathrm{~m}$ in Albatross Bay, Gulf of Carpentaria, Australia ( $n=5$ )

\begin{tabular}{|cccc|}
\hline $\begin{array}{c}\text { Pore size } \\
(\mu \mathrm{m})\end{array}$ & Nuclepore & Poretics $^{(}$ & Whatman $^{\text {G }}$ GF/F \\
\hline 0.6 & $1.53(0.08)$ & $1.24(0.05)$ & $1.12(0.11)$ \\
2.0 & $1.18(0.05)$ & $1.00(0.10)$ & \\
10.0 & $1.00(0.08)$ & $0.76(0.05)$ & \\
\hline
\end{tabular}


Table 2. Absorbance (665 nm) of Tetraselmis suecica cells collected on filters and extracted in methanol. Three brands of filter were used: Nuclepore ${ }^{(8)}$ polycarbonate $(0.6 \mu \mathrm{m})$, Poretics ${ }^{(*)}$ polycarbonate $(0.6 \mu \mathrm{m})$ and Whatman ${ }^{*} \mathrm{GF} / \mathrm{F}$ glass-fibre filters. Three different cell numbers were filtered $(n=2)$

\begin{tabular}{|cccc|}
\hline $\begin{array}{c}\text { No. of cells } \\
\text { filtered }\left(\times 10^{6}\right)\end{array}$ & Nuclepore & Poretics & Whatman $^{*} \mathrm{GF} / \mathrm{F}$ \\
\hline 0 & 0.003 & 0.000 & 0.000 \\
1 & 0.015 & 0.010 & 0.010 \\
5 & 0.047 & 0.056 & 0.053 \\
10 & 0.102 & 0.103 & 0.104 \\
\hline
\end{tabular}

The effect of the contaminant on chlorophyll a measurements is more pronounced when the amount of phytoplankton pigment on a filter is low. The absorbance maxima $(665 \mathrm{~nm})$ of 3 quantities $\left(1 \times 10^{6}\right.$, $5 \times 10^{6}$ and $10^{7}$ cells) of a Tetraselmis suecica culture filtered onto polycarbonate and glass-fibre filters were compared with blank filters (Table 2). The absorbance value of Nuclepore ${ }^{*}$, in the absence of algae, was 0.003 , compared with 0.000 for Poretics ${ }^{\otimes}$ and What$\operatorname{man}^{1}$. At low algal quantities, $1 \times 10^{6}$ cells, the interference of the contaminant was obvious; however, at higher concentrations, i.e. $5 \times 10^{6}$ and $10^{7}$ cells, there is no apparent difference between the type of filters used. This is because the percentage of the contaminating dye decreases as more chlorophyll is collected. At approximately $0.05 \mathrm{Abs}$, the absorbance due to the dye is so small, as a percentage of the total amount of chlorophyll, no differences are seen between the filter types used.

HPLC chromatograms of the Nuclepore ${ }^{\circledast}$ filter extracts, without phytoplankton, had a discrete peak (Peak 6, Fig. 3A) which was not present in Poretics ${ }^{\circledR}$ polycarbonate filter extracts (Fig. 3B). This peak occurs in the same region as chlorophyll-related pigments (Peaks 4, 5) in phytoplankton samples; however, it does not interfere directly with them (Fig. 3C).

Nuclepore ${ }^{\circledR}$ and Poretics ${ }^{\circledR}$ polycarbonate filters extracted in either acetone or methanol did not fluoresce. They do not, therefore, interfere with the fluorometric analysis of chlorophyll a.

Discussion. It is imperative that researchers interested in phytoplankton pigments are aware of the presence of this contaminant which is extracted from Nuclepore ${ }^{\otimes}$ polycarbonate filters into methanol, because it renders these filters unsuitable for spectrophotometric analysis. This is particularly important in studies of phytoplankton collected from waters where pigment concentrations are low. It is not always possible to reduce the effect of the contaminant by increasing the amount of phytoplankton filtered, since membrane filters are easily overloaded and

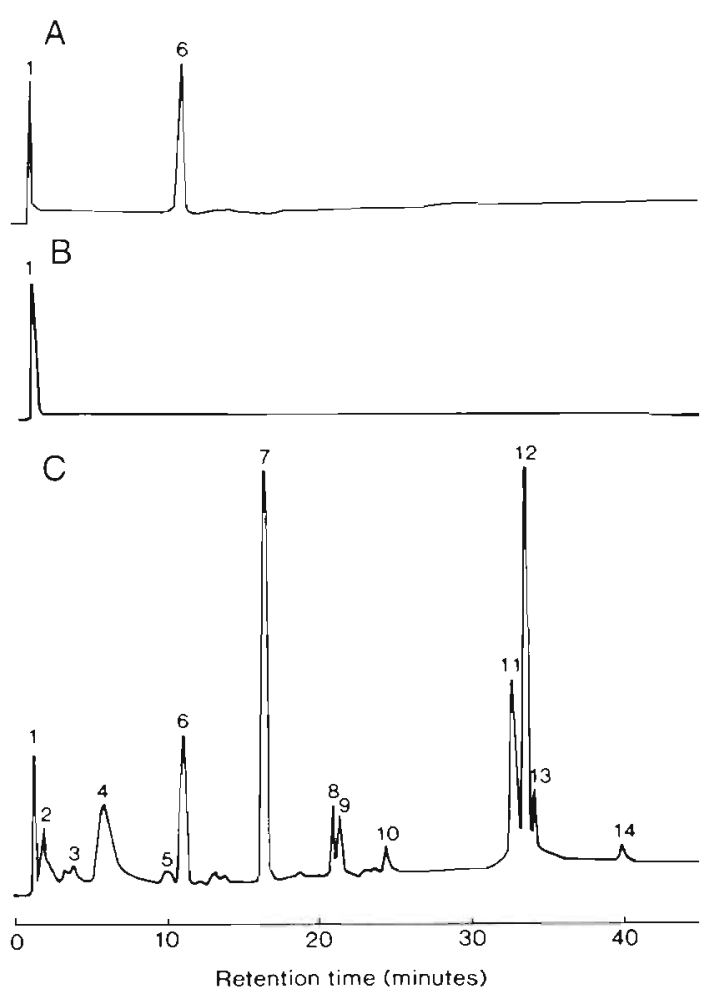

Fig. 3. High performance liquid chromatographs of methanol extracts of (A) Nuclepore ${ }^{(}$polycarbonate filter, (B) Poretics ${ }^{(6)}$ polycarbonate filter, and (C) phytoplankton collected on Nuclepore ${ }^{\circledR}$ polycarbonate filters. Peak identifications: (1) solvent front; ( $2 \& 3$ ) chlorophyllide a-related $;$ (4) chlorophyll crelated; (5) chlorophyll-related; (6) Nuclepore ${ }^{\otimes}$ contaminant; (7) fucoxanthin; (8) diadinoxanthin; (9) diatoxanthin; (10) lutein/zeaxanthin; $\left(11,12\right.$ \& 13) chlorophyll $a_{i}$ (14) carotenes

nominal pore sizes become altered precluding size class separation.

Our results suggest that when chlorophyll a concentrations are approximately $1 \mathrm{\mu g}^{-1}$ or less $\left(10^{5}\right.$ to $10^{6}$ cells $1^{-1}$ ), the dye will interfere with spectrophotometric analysis. These concentrations are commonly found in oligotrophic waters. This problem will be particularly pronounced when the sample contains a high proportion of particulates since the membrane filters will become clogged more rapidly and the volume filtered will be reduced.

In contrast, the use of HPLC separates chlorophylls and carotenoids from the Nuclepore ${ }^{\infty}$ contaminant. In recent years, HPLC has become a commonly used technique for providing information about the community composition of the phytoplankton (Gieskes et al. 1988, Colijn et al. 1990, Everitt et al. 1990). The use of acetone for extraction is not an alternative because it partially dissolves the Nuclepore ${ }^{\circledR}$ polycarbonate filters. A colloid that cannot be removed by filtration or centrifugation results. 
Fluorometric analysis is another common procedure for determining chlorophyll a (Strickland \& Parsons 1972). In addition, spectrofluorometers are often used as detectors for HPLC analysis of chlorophylls (Bidigare et al. 1985). The dye present in Nuclepore ${ }^{\circledR}$ polycarbonate filters does not fluoresce and therefore will not interfere with this method.

Poretics ${ }^{(}$polycarbonate filters do not appear to contain this contaminant, however the disadvantage of Poretics $^{\otimes}$ polycarbonate filters is that the efficiency of their particle retention is less than that of Nuclepore ${ }^{(3)}$. This is due to the presence of large holes or pores, some of which are 5 times larger than the nominal pore size (Stockner et al. 1990). Nuclepore ${ }^{(3)}$ polyester membrane filters are stable in organic solvents and have been used successfully by others for phytoplankton pigment analysis (Ondrusek et al. 1991). A range of pore sizes are available that could be used for size class studies of phytoplankton.

Acknowledgements. We thank Mark O'Donohue for assistance with analyses. Peter Rothlisberg, Miles Furnas, Peter Nichols and Vivienne Mawson offered constructive criticism of early drafts of this manuscript. Kevin Dobson made available the use of a spectrofluorometer. The work was made possible by a Fishing Industry Research and Development Account grant (89/13).

\section{LITERATURE CITED}

Bidigare, R. R., Kennicutt, M. C., Brooks, J. M. (1985). Rapid determination of chlorophylls and their degradation products by high performance liquid chromatography. Limnol. Oceanogr. 30: $432-435$

Colijn, F., Villerius, L., Rademaker, M., Hammer, K. D., Eberlein, K. (1990). Changes in spatial distribution of primary

This note was submitted to the editor production, photosynthetic pigments and phytoplankton species composition during two surveys in the German Bight. Neth. J. Sea Res. 25: 155-164

Everitt, D. A., Wnght, S. W., Volkman, J. K., Thomas, D. P., Lindstrom, E. J. (1990). Phytoplankton community compositıons in the western equatorial Pacific determined from chlorophyll and carotenoid pigment distributions. Deep Sea Res. 37: 975-997

Furnas, M. J., Mitchell, A. W., Gilmartin, M., Revelante, N. (1990). Phytoplankton biomass and primary production in semi-enclosed reef lagoons of the central Great Barrier Reef, Australia. Coral Reefs 9: 1-10

Gieskes, W. W. C., Kraay, G. W. (1983). Dominance of Cryptophyceae during the phytoplankton spring bloom in the central North Sea detected by HPLC analysis of pigments. Mar. Biol. 75: 179-185

Gieskes, W. W. C., Kraay, G. W., Nontji, A., Setiapermana, D., Sutomo (1988). Monsoonal alternation of a mixed and a layered structure in the phytoplankton of the euphotic zone of the Banda Sea (Indonesia): a mathematical analysis of algal pigment fingerprints. Neth. J. Sea Res. 22: 123-137

Joint, I. R., Pomroy, A. J. (1983). Production of picoplankton and small nanoplankton in the Celtic Sea. Mar. Biol. 77 $19-27$

Ondrusek, M. E., Bidigare, R. R., Sweet, S. T., Defreitas, D. A., Brooks, J. M. (1991). Distribution of phytoplankton pigments in the North Pacific in relation to physical and optical variability. Deep Sea Res. 38: 243-266

Rowan, K. S. (1989). Photosynthetic pigments of algae. Cambridge Unversity Press, Cambridge

Stockner, J. G., Emilia Klut, M., Cochlan, W. P. (1990). Leaky filters: a warning to ecologists. Can. J. Fish. Aquat. Sci. 47 $16-23$

Strickland, J. D., Parsons, T R. (1972). A practical handbook of seawater analysis, 2nd edn. Bull. Fish. Res. Bd Can. 167

Williams, R., Claustre, H. (1991). Photosynthetic pigments as biomarkers of phytoplankton populations and processes involved in the transformation of particulate organic matter at the Biotrans site $\left(47^{\circ} \mathrm{N}, 20^{\circ} \mathrm{W}\right)$. Deep Sea Res. 38 : $347-355$

Manuscript first received: April 14, 1993

Revised version accepted: September 16, 1993 